\title{
Research on the Construction of Second-hand Commodity Trading Website on Campus
}

\author{
WU Yanxia ${ }^{1, a}$, Nie Guolin ${ }^{2, b}$ \\ ${ }^{1}$ Institute of humanities, Jiangxi University of Traditional Chinese Medicine, Nan Chang, 330004, \\ China \\ ${ }^{2}$ The Organization Department, Jiangxi University of Traditional Chinese Medicine, Nan Chang, \\ 330004, China \\ aemail: wuyanxia2000@sina.com
}

Keywords: Second - hand Commodity, Trading Website

\begin{abstract}
Second - hand goods trading has become a popular thing in ecollege students' spare time. At present, there are various kinds of information issuing platforms on the market, such as the Net barter, the exchange net, but the content of information issued is less well-directed, the arragement of information is messy, which can't match the students' demand, so that the customer usually has to waste much time on screening out the information they need. The information platform designed for our college students is not yet formed. Therefore, in view of the needs of students, it is feasible and necessary to establish second-hand Commodity Trading Website.
\end{abstract}

\section{Introduction}

At present, second-hand goods trading has become a popular thing in ecollege students' spare time, our school every year hold the booming "flea" market, we can see the demand for second-hand commodity transactions. Unfortunately, the school's second-hand transactions are often short-lived, far from being able to meet the needs of our university students. At present, there are various kinds of information issuing platforms on the market, such as the Net barter, the exchange net, but the content of information issued is less well-directed, the arragement of information is messy, which can't match the students' demand, so that the customer usually has to waste much time on screening out the information they need. The information platform designed for our college students is not yet formed. Therefore, in view of the needs of students, it is feasible and necessary to establish second-hand Commodity Trading Website.

The customers of the site are only the university campus network users, so the system scale is not great. In term of economy, it is feasible because the development tools and servers are almost entirely free open source software, and because Web-based B / S model is low-cost. In term of technique, it can be relatively easy to supply the actual needs of users because it is based on the Web and at the same time there are many successful e-commerce site experience that can be learnt from. In term of the operating, it is feasible because the client just need a browser, through which they can log in the system. At the same time such a system, in the legitimate management of the system administrator and the user's conscious cooperation, will not violate any illegal activities and transactions and release any harmful and inappropriate information, there is no illegal profit-making behavior, so it is feasible in leagall.

\section{Design of campus second-hand commodity trading website}

\section{The design principle of second - hand commodity trading website.}

Before the design of "campus second-hand commodity trading website", we have to determine the design principle of the site, simply speaking, determine the site theme and style based on the site's audience, discipline characteristics and teaching rules. The determination of theme and style is an important prerequisite for website design and production.

The theme of the site is the specific content that the viewer sees from the site. And the style of 
the site is the presentation form of this specific content. The former is the core of the site, is the basis for the site development, and the latter is the form of this specific content. The establishment of a good site requires a good theme. Website style settings are mainly from two aspects of the content. One is the visual effects of the site, and the other is the functional content of the site.

The basic characteristics of campus second-hand commodity trading website.

The system uses Photoshop + Dreamweaver + Flash for static web design, and uses IIS + Sql server + Asp.net for dynamic interactive function development. The basic features are as follows:

\begin{tabular}{|c|l|}
\hline $\begin{array}{c}\text { Business } \\
\text { Scope }\end{array}$ & $\begin{array}{l}\text { Provide all the trading information of the second-hand items, } \\
\text { including books, mobile phones, sporting goods, computers, } \\
\text { digital product, others closely related with the school life. }\end{array}$ \\
\hline $\begin{array}{c}\text { Operating } \\
\text { mode }\end{array}$ & $\begin{array}{l}\text { Led by the team leader to carry out the work, with } \\
\text { each team memeber putting in charge of the different } \\
\text { work. }\end{array}$ \\
\hline $\begin{array}{c}\text { Trading } \\
\text { principles }\end{array}$ & $\begin{array}{l}\text { Equal voluntary transactions, customer satisfaction } \\
\text { first, real-name registration system, refuse illegal } \\
\text { transactions. }\end{array}$ \\
\hline $\begin{array}{c}\text { Promotion } \\
\text { strategies }\end{array}$ & $\begin{array}{l}\text { In the first two months take a free transaction; in the campus } \\
\text { network publish a large number of promotional information; in } \\
\text { the the QQ group with more school students publish } \\
\text { information, carry out promotional activities, set up booths and } \\
\text { other strategies to gather popularity for the site and open the } \\
\text { market. }\end{array}$ \\
\hline $\begin{array}{c}\text { Marketing } \\
\text { strategies }\end{array}$ & $\begin{array}{l}\text { Sell secondhand goods on com-mission, barter, second-hand } \\
\text { sale, second-hand purchase and so on }\end{array}$ \\
\hline
\end{tabular}

\section{Campus second-hand commodity trading site's main function modules.}

Campus second-hand commodity trading site design various modular, in order to make different modules be independent of each other, that is easy to achieve and easy to maintain, while the software more reliable. The system mainly designed the personnel information management module, commodity presentation module, shopping cart module, commodity management module, order management module, as shown below: 


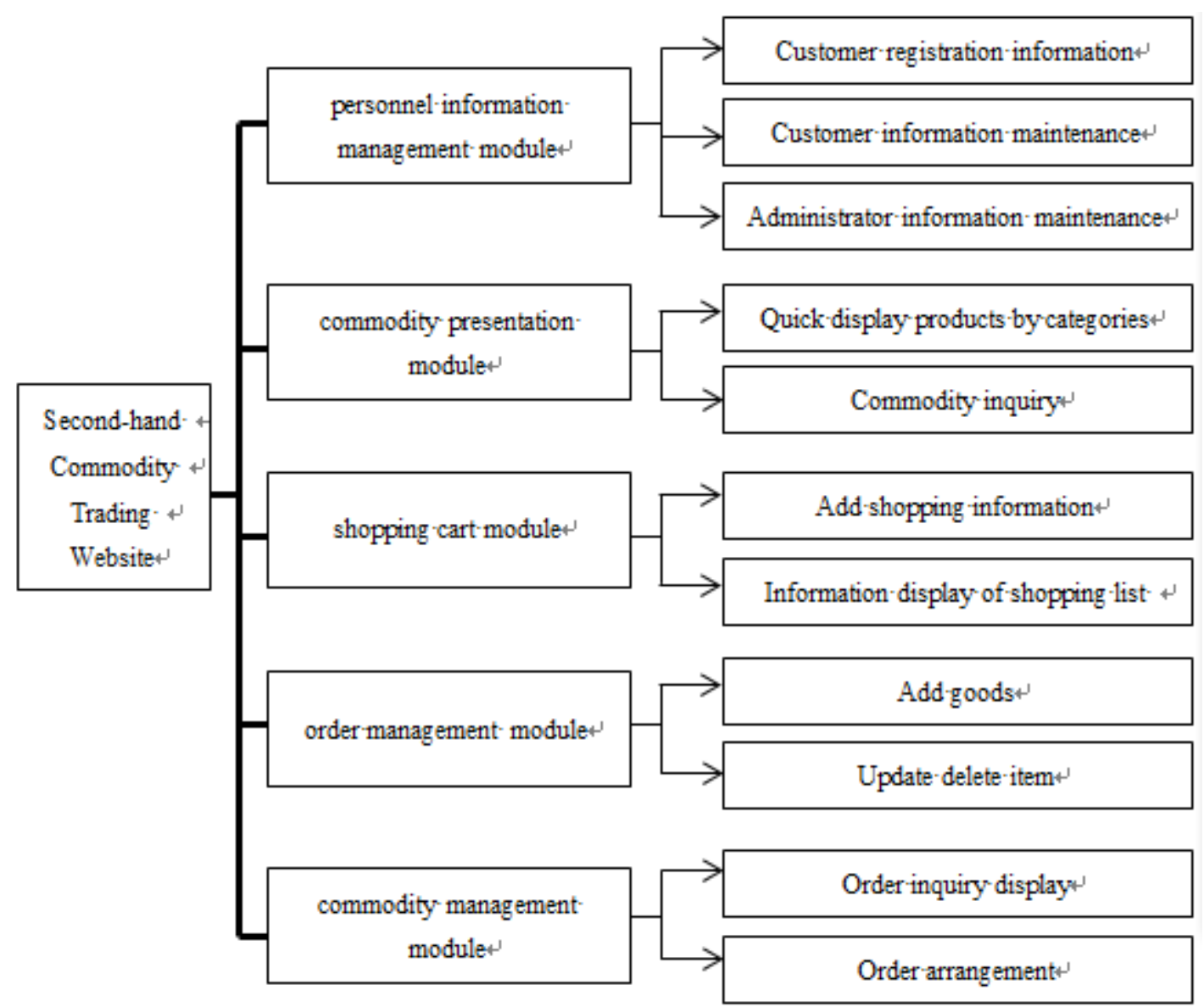

The main interface table of the campus second-hand Commodity trading site.

The interface of this website adheres to the concept of "serve for customers", which consist of the main interface, registration column, product list, I want to sell, shopping cart, view orders, message board:

\begin{tabular}{cc}
\hline website modular & Web pages names \\
\hline the main interface & Index.aspx \\
product list & product.aspx \\
shopping cart & shopcart.aspx \\
I want to sell & productadd.aspx \\
view orders & orderlist.aspx \\
message board & liuyan.aspx \\
registration column & regiser.aspx \\
\hline
\end{tabular}

\section{The trading Process of Campus second-hand Commodity Trading Website.}

A good site, its knowledge structure should be complete and comprehensive, and its presentation should be jumping and flexible. In the process of leaking to show the content of teaching, it focuses on the knowledge of navigation, that is, at any time it provide the knowledge structure guide of the entire site for the learners. So that learners always know what part of the study itself is in the position of the whole knowledge structure, what is the relevant content before and after it. So that the learners will not be lost in the vast sea of knowledge. Whereby the transaction process of the second-hand commodity trading website is as follows: 


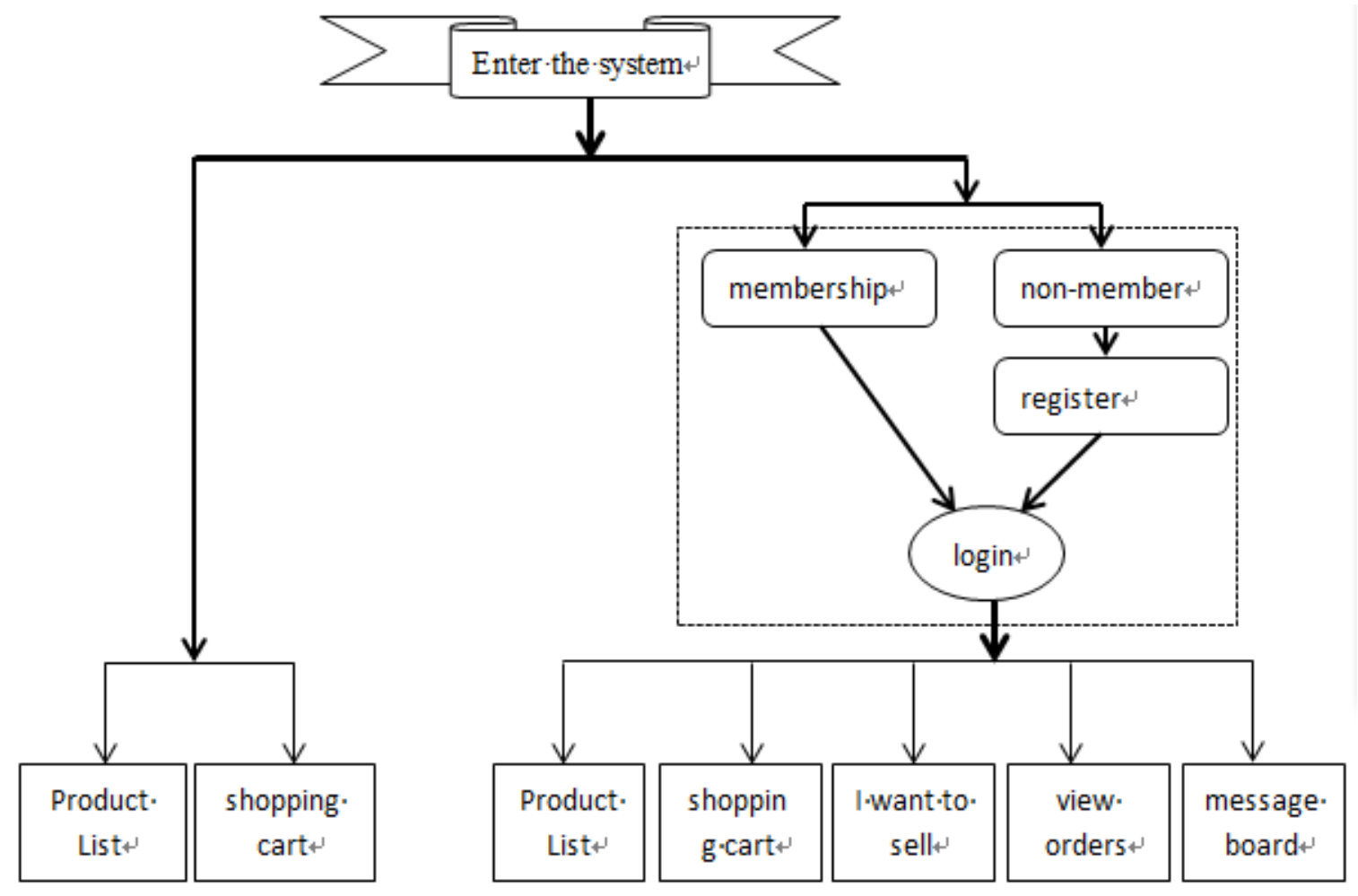

\section{To sum up}

According to the above design of Second-hand Commodity Trading Website on Campus, Some conclusions have been drawn from the research as follow:

1) This website provide a win-win platform for buyers and sellers. Sellers are no longer anxious that old things can not't be handled, which can sell a reasonable price. Buyer can buy a satisfactory item at a low price.

2) To achieve energy-saving and emission-reduction. Both sides of the transaction can make effective use of resources to promote the environmental protection and the effective use of social resources.

3) To promote the development of second-hand transactions. The convenience of the network will also make more and more students be accustomed to buying and selling second-hand items on the network, and no longer need to visit the traditional second-hand market.

4) It breaks the boundaries of time and space, and change the trade pattern.

\section{Acknowledgements}

This work is supported by Research on Humanities and Social Sciences in Jiangxi Province (GL1329).

\section{References}

[1] Luo Zhihuang. Teacher personal network and educational information network [J] .International Education Research, 2001 (3).

[2] Qiu Huiqi, Yan Xiao Juan. Some thoughts on the construction of teaching website [J]. audio visual education research, 2005 (11).

[3] Wang Jiehua, Su Feng. Basic course of traditional Chinese medicine [M]. Zhengzhou: Henan science and Technology Press, 2008.

[4] Wang Xiaoke, Liu Lili. The full record of ASP.NET typical module development [M]. Beijing: Tsinghua University press, 2010. 
[5] Xiao Ying et al. Construction of anesthesia teaching website and its application in teaching [J]. Chinese medical education technology, 2015 (6).

[6] Yangyin, Zhang Yongxiong. Chinese version of Dreamweaver + Flash + Photoshop web page from entry to master [M]. Beijing: Tsinghua University press, 2010. 